\title{
UMOWA O PRACĘ JAKO PODSTAWA NAWIAZZANIA STOSUNKU PRACY Z NAUCZYCIELEM AKADEMICKIM. WNIOSKI DE LEGE LATA I DE LEGE FERENDA
}

\author{
Abstract \\ Employment contract as a basis of employment relationship with a scholar. De lege lata \\ and de lege ferenda proposals
}

The goal of this article is to determine, which norms of labor law should be applied to the employment contract of definite duration with a scholar in a regard to the permissible amount of concluded contracts and their duration.

The author analyses the influence of Polish Labor Code (PLC) amendment from 16 December 2016 in scope of provisions regulating definite duration employment contracts. For the purpose of this article, relevant provisions of Act on the Higher Education are analyzed, in particular art. 118a. In conclusion, art. 25 and following of PLC should be applied to the employment contracts of definite duration concluded with scholars. Although such contracts may be concluded for duration longer than 33 months, conditions set forth by art. $25^{1} \S 4$ PLC must be therefore fulfilled.

Słowa kluczowe: umowa o pracę na czas określony, szkolnictwo wyższe, mianowanie

Key words: employment contract of definite duration, higher education, appointment

Przedmiotem opracowania jest określenie podstaw prawnych stosowania umowy o pracę jako aktu kreującego stosunek pracy nauczyciela akademickiego, zatrudnionego w szkole wyższej. Problem ten jawi się jako istotny z co najmniej dwóch powodów. Pierwszym $\mathrm{z}$ nich jest określenie prawa właściwego dla stosowania tej podstawy nawiązania stosunku pracy, biorąc pod uwagę pragmatyczne uregulowania ustawy z dnia 27 lipca 2005 r. Prawo o szkolnictwie wyższym ${ }^{1}$ (dalej ustawa Pr. o szk. wyższ.) w relacji z powszechnymi normami prawa pracy, określonymi w Kodeksie pracy (dalej kp). Drugim aspektem, przy założeniu, że normy ustawy Pr. o szk. wyższ. nie mają charakteru kompletnego, jest mechanizm stosowania znowelizowanych norm kp o terminowych umowach o pracę

\footnotetext{
1 Dz. U. z 2016 r., poz.1842 j.t. z późn. zm.
} 
i obowiązku zawarcia umowy o pracę na czas nieokreślony. Nie mniej istotnym elementem analizy tak zdefiniowanego zakresu przedmiotowego opracowania jest tocząca się w środowisku szkolnictwa wyższego dyskusja na temat nowych założeń projektowanej ustawy o szkolnictwie wyższym, która zgodnie z deklaracjami Ministerstwa Nauki i Szkolnictwa Wyższego ma wejść w życie z początkiem roku akademickiego 2018/2019, stąd poza wnioskami de lege lata opracowanie zawiera także tezy de lege ferenda w odniesieniu do podstawy nawiązania stosunku pracy z nauczycielem akademickim.

Zakres objętościowy artykułu determinuje skoncentrowanie uwagi na normatywnych podstawach stosowania umowy o pracę jako podstawy nawiązania stosunku pracy, z uwzględnieniem jej rodzajów i pozostawienie poza przedmiotem rozważań problematyki sposobów jej zawarcia, treści, zmiany treści i rozwiązania oraz wygaśnięcia.

\section{Uwagi ogólne o umowie o pracę}

Umowa o pracę stanowi najczęściej stosowaną podstawę nawiązania zobowiązaniowego stosunku pracy, wskazaną w ramach enumeratywnego wyliczenia w art. $2 \mathrm{kp}$. W wyniku zawarcia umowy o pracę dochodzi do powstania tak zwanego umownego stosunku pracy. Z uwagi na fakt, że przepisy nie określają przypadków, w których stosunek pracy kreuje się na podstawie umowy o pracę, przyjmuje się, że jej zawarcie uzależnione jest od istnienia dwóch przesłanek. Po pierwsze, przesłanki negatywnej, co oznacza, że ma to miejsce, gdy odrębna regulacja nie wskazuje innej podstawy nawiązania stosunku pracy, a po drugie, przesłanki pozytywnej w takim rozumieniu, że o zawarciu umowy o pracę decyduje nie tyle rodzaj wykonywanej pracy, ile warunki jej wykonywania ${ }^{2}$. Nawet jednak w przypadku, gdy umowa o pracę zostaje zawarta w miejsce wymaganej przez przepisy prawa pracy podstawy pozaumownej, wątpliwe z prawnego punktu widzenia jest unieważnienie takiej umowy ${ }^{3}$. Umowa o pracę jest czynnością konsensualną, co oznacza, że dochodzi do skutku, gdy strony złożą zgodne oświadczenie co do jej istotnych postanowien ${ }^{4}$.

W kontekście umowy o pracę jako podstawy nawiązania stosunku pracy kluczowe znaczenie, także w wymiarze praktycznym, ma zagadnienie jej rodzajów oraz obowiązku zawarcia bezterminowej umowy o pracę. Problem rodzajów umowy o pracę kształtowany jest $\mathrm{w}$ obowiązującym stanie prawnym w odniesieniu do powszechnego prawa pracy przede wszystkim poprzez treść art. 25 i $25^{1} \mathrm{kp}$, nadaną na mocy nowelizacji dokonanej ustawą z dnia 25 czerwca 2015 r. o zmianie ustawy - Kodeks pracy oraz niektórych innych

2 Por. M. Tomaszewska, w: Kodeks pracy. Komentarz, K.W. Baran (red.), Warszawa 2012, s. 194; J. Stelina, Charakter prawny stosunku pracy z mianowania, Gdańsk, 2005, s. 32; por. także J. Stelina, w: Leksykon prawa pracy. 100 podstawowych pojęć, J. Stelina (red.), Warszawa 2008, s. 316-317.

3 Tak: wyrok SN z dnia 7 lipca 2005 r., II PK 351/04, OSNP 2006, nr 11-12, poz. 171.

4 Tak: postanowienie SN z dnia 22 listopada 1979 r., III PZ, 7/79, Praca i Zabezpieczenie Społeczne 1981, 7, s. 53. 
ustaw $^{5}$, która w analizowanym zakresie weszła w życie 22 lutego 2016 r. Choć brzmienie przywołanych przepisów sprzed przedmiotowej nowelizacji ma w chwili obecnej jedynie wymiar historyczny, to porównanie aktualnego stanu prawnego z poprzednio obowiązującym jawi się istotnym z punktu widzenia problematyki niniejszego opracowania.

Do 22 lutego 2016 r. rodzaje umowy kp określał w postaci katalogu zamkniętego, stanowiąc w art. 25 o umowie na czas określony, w tym w okolicznościach zastępstwa pracownika nieobecnego z usprawiedliwionych przyczyn, umowie na czas nieokreślony, umowie na czas wykonania określonej pracy oraz o umowie na okres próbny. Dodatkowo art. 194 kp normował umowę o pracę w celu przygotowania zawodowego, art. $206 \mathrm{kp}$ wskazywał zaś umowę o pracę o przygotowanie zawodowe u pracodawców będących rzemieślnikami, a art. $77 \S 1 \mathrm{kp}$ - spółdzielczą umowę o pracę, zawieraną pomiędzy członkiem spółdzielni pracy a samą spółdzielnią. De lege lata art. $25 \mathrm{kp}$ stanowi, że umowę o pracę zawiera się na okres próbny, na czas nieokreślony albo na czas określony, z czego wynika, że ustawodawca zrezygnował z typizacji umowy na czas wykonania określonej pracy. Przepisy art. 194 kp, art. 206 kp oraz art. $77 \$ 1$ kp zachowały swoją aktualność.

Wspomniana nowelizacja przepisów kp wprowadziła także fundamentalne zmiany w zakresie obowiązku zawarcia umowy na czas nieokreślony. W poprzednio obowiązującym stanie prawnym to sekwencyjność umów, a nie czas ich trwania ${ }^{6}$, była tu czynnikiem kluczowym, zgodnie $\mathrm{z}$ art. $25^{1} \mathrm{kp}$ bowiem w brzmieniu sprzed analizowanej nowelizacji po dwukrotnym zawarciu umowy na czas określony statuował się obowiązek zawarcia umowy na czas nieokreślony, z zastrzeżeniem, że odstęp czasowy pomiędzy umowami nie mógł przekraczać jednego miesiąca. Zgodnie $\mathrm{z}$ aktualną treścią art. $25^{1} \mathrm{kp}$ o obowiązku zawarcia bezterminowej umowy o pracę decyduje już nie tylko liczba zawartych pomiędzy stronami umów na czas określony (maksymalnie 3), lecz także łączny czas ich trwania (maksymalnie 33 miesiące). Naruszenie któregokolwiek z tak sformułowanych ograniczeń spowoduje, że pracownik, odpowiednio od dnia następującego po upływie okresu 33 miesięcy lub od dnia zawarcia czwartej umowy o pracę na czas określony, będzie zatrudniony na podstawie umowy o pracę na czas nieokreślony.

Co istotne, dla tak zdefiniowanego mechanizmu wymogu bezterminowej umowy o pracę ustawodawca wprowadził wyjątki, w których dopuszczalne będzie przekroczenie limitu liczby umów na czas określony oraz czasu ich trwania. Będzie to możliwe

5 Dz. U. z 2015 r., poz. 1220.

${ }^{6} \mathrm{Na}$ ten temat zob. w szczególności: K. Łapiński, Ograniczenia w zawieraniu umów terminowych w polskim prawie pracy, Monitor Prawa Pracy 2007, 4, s. 182 i n.; U. Jackowiak, Terminowe umowy o prace a ochronna funkcja prawa pracy, Monitor Prawa Pracy 2004, 4, s. 96 i n.; K.W. Baran, Umowa o pracę na czas określony w ustawie o łagodzeniu skutków kryzysu ekonomicznego dla pracowników i przedsiębiorców, Monitor Prawa Pracy 2009, 9, s. 455 i n.; A. Sobczyk, O czasie trwania umowy zawartej na czas określony, w: Z zagadnień współczesnego prawa pracy. Księga jubileuszowa Profesora Henryka Lewandowskiego, Z. Góral (red.), Warszawa 2009, s. 313 i n.; M. Gersdorf, O przyczynowości zawarcia i rozwiązania umowy na czas określony, w: Stosunki zatrudnienia $w$ dwudziestoleciu społecznej gospodarki rynkowej. Księga pamiątkowa z okazji jubileuszu 40-lecia pracy naukowej Profesor Barbary Wagner, A. Sobczyk (red.), Warszawa 2010, s. 217 i n. 
w przypadku umów o pracę zawartych na czas określony: w celu zastępstwa pracownika w czasie jego usprawiedliwionej nieobecności w pracy; w celu wykonywania pracy o charakterze dorywczym lub sezonowym; w celu wykonywania pracy przez okres kadencji; w przypadku gdy pracodawca wskaże obiektywne przyczyny leżące po jego stronie. W każdej jednak z enumeratywnie wymienionych sytuacji pojawia się wymóg, aby uczynienie wyjątku służyło zaspokojeniu rzeczywistego okresowego zapotrzebowania i było niezbędne w tym zakresie, w świetle wszystkich okoliczności zawarcia umowy. Dodatkowo, kiedy pracodawca przekroczy limit liczbowy umów lub maksymalny czas ich trwania, powołując się na obiektywne przyczyny leżące po jego stronie, będzie miał obowiązek zawiadomienia o tym fakcie w formie pisemnej lub elektronicznej właściwego okręgowego inspektora pracy w terminie 5 dni roboczych od dnia zawarcia przedmiotowej umowy, wskazując jednocześnie przyczynę uzasadniającą tego rodzaju działanie.

\section{Umowa o pracę w sferze szkolnictwa wyższego de lege lata}

Ustawa z dnia 27 lipca 2005 r. Prawo o szkolnictwie wyższym ${ }^{7}$, w dniu jej wejścia w życie, to jest 1października 2005 r., ukonstytuowała dualistyczny system podstawy nawiązania stosunku pracy z nauczycielem akademickim, przy czym aktualnie obowiązujące przepisy ukształtowała ustawa nowelizująca $\mathrm{z}$ dnia 18 marca $2011 \mathrm{r}^{8}$ Znowelizowany art. 118 ustawy Pr. o szk. wyższ. powiela dualizm aktu kreującego stosunek pracy nauczyciela akademickiego, stwierdzając, że nawiązanie stosunku pracy następuje na podstawie mianowania ${ }^{9}$ albo umowy o pracę ${ }^{10}$, a mianowanie musi łączyć się z pełnym wymiarem czasu pracy. W dodanym zdaniu drugim omawianego przepisu stwierdza się jednak, że na podstawie mianowania zatrudnia się wylącznie nauczyciela akademickiego posiadającego tytuł naukowy profesora. Na mocy omawianej ustawy nowelizującej utrzymano w mocy ust. 2 art. 121 ustawy Pr. o szk. wyższ., zgodnie z którym mianowanie może następować na czas określony albo nieokreślony, natomiast skreśleniu uległ ust. 3 tego przepisu, który wskazywał procedurę konkursową, regulowaną przepisem statutu uczelni w kontekście zatrudnienia nauczyciela akademickiego na podstawie mianowania. Przepis ten został zastąpiony przez dodany art. 118a ustawy Pr. o szk. wyższ., wprowadzający procedurę

7 Dz. U. z 2015r., Nr 164, poz. 1365 z późn. zm.

8 Ustawa z 18 marca 2011 r. o zmianie ustawy - Prawo o szkolnictwie wyższym, ustawy o stopniach naukowych i tytule naukowym oraz o stopniach i tytule w zakresie sztuki oraz o zmianie niektórych innych ustaw (Dz. U., Nr 84, poz. 455).

${ }_{9} \mathrm{Na}$ ten temat zob. w szczególności: T. Kuczyński, Właściwości opisujące nawiązanie nominacyjnego stosunku pracy, w: Z aktualnych zagadnień prawa pracy i zabezpieczenia społecznego. Księga jubileuszowa Profesora Waleriana Sanetry, B. Cudowski, J. Iwulski (red.), Warszawa 2013, s. 219 i n.

${ }^{10} \mathrm{Na}$ ten temat zob. w szczególności: K.W. Baran, O niektórych sposobach nawiązania umownego stosunku pracy, w: Wolność i sprawiedliwość w zatrudnieniu. Księga pamiątkowa poświęcona Prezydentowi Rzeczypospolitej Polskiej Profesorowi Lechowi Kaczyńskiemu, M. Seweryński, J. Stelina (red.), Gdańsk 2012, s. 19 i n. 
konkursową w związku z nawiązaniem stosunku pracy z nauczycielem akademickim, przy czym już bez względu na rodzaj aktu kreującego.

W odniesieniu do umowy o pracę, jako podstawy nawiązania stosunku pracy z nauczycielem akademickim, należy najpierw rozstrzygnąć problem zmierzający do udzielenia odpowiedzi na pytanie, czy regulacja ustawy Pr. o szk. wyższ. ma charakter wyczerpujący, i to w zakresie jej norm należy dokonywać analizy przedmiotowego problemu, czy też w związku z brakiem regulacji należy na zasadzie odesłania stosować przepisy kp. Biorąc pod uwagę treść przywołanej wyżej normy art. 118 ustawy Pr. o szk. wyższ., która ogranicza się jedynie do wskazania umowy o pracę jako podstawy nawiązania stosunku pracy, można byłoby dojść do wniosku, że mechanizm posiłkowego stosowania norm $\mathrm{kp}$ o umowie o pracę, na podstawie odesłania $\mathrm{z}$ art. 136 ust. 1 ustawy Pr. o szk. wyższ., jest uzasadniony. Jak słusznie podkreśla się jednak w doktrynie, „dla uznania, że określona sprawa nie została uregulowana w rozumieniu dyrektywy art. $5 \mathrm{kp}$, niewystarczający jest sam fakt braku przepisu w pragmatyce, odpowiadającego konkretnemu przepisowi Kodeksu pracy, lecz należy jeszcze ustalić, czy brzmienie szczególnego uregulowania pragmatyki zastępuje, choćby w najogólniejszy sposób, instytucje Kodeksu pracy." ${ }^{11}$ Analiza normy art. 118a ustawy Pr. o szk. wyższ., która po nowelizacji z roku 2011 uniformizuje podstawę nawiązania stosunku pracy z nauczycielem akademickim, wydaje się spełniać tego rodzaju funkcję, bo choć dotyczy postępowania konkursowego w sprawie zatrudnienia nauczyciela akademickiego, to jej treść stanowi podstawę do określenia rodzajów umowy o pracę zawieranej z nauczycielem akademickim w sposób niezależny od przepisów kp. Odrębną kwestią pozostaje to, czy w pozostałym zakresie, istotnym z punktu widzenia przedmiotu niniejszego opracowania, odnoszącym się do tej podstawy nawiązania stosunku pracy, obowiązują podobne normy ustawy Pr. o szk. wyższ., wyłączające stosowanie ogólnych przepisów kp, o czym mowa niżej.

Biorąc pod uwagę powyższe spostrzeżenie na temat treści art. 118a ustawy Pr. o szk. wyższ., można zatem w sposób jednoznaczny stwierdzić, że problematyka rodzajów umowy o pracę, zawieranych w szkole wyższej z nauczycielem akademickim, jest uregulowana w ustawie Pr. o szk. wyższ. w sposób zupełny, co oznacza, że zastępuje ona w analizowanym zakresie katalog umów z art. $25 \mathrm{kp}$. Zgodnie z art. 118a ust. 1 zd. 1 ustawy Pr. o szk. wyższ. nawiązanie stosunku pracy z nauczycielem akademickim na uczelni publicznej, na czas określony lub nieokreślony, $\mathrm{w}$ wymiarze przekraczającym połowę pełnego wymiaru czasu pracy, następuje po przeprowadzeniu otwartego konkursu. Biorąc pod uwagę wspomnianą na początku opracowania zmianę zakresu podmiotowego postępowania konkursowego, która de lege lata obejmuje obie podstawy nawiązania stosunku pracy z nauczycielem akademickim, uwzględniając także użyte przez ustawodawcę pojęcia tożsame z rodzajami

${ }_{11}$ T. Kuczyński, Komentarz do art. 118 ustawy Pr. o szk. wyższ., w: Akademickie prawo pracy. Komentarz do art. 107-158 oraz 196-201a i 226 ustawy Prawo o szkolnictwie wyższym, K.W. Baran (red.), Warszawa 2015, s. 73. 
umowy o pracę z kp, można $\mathrm{z}$ kontekstu normatywnego ${ }^{12}$ wnioskować o wynikającej $\mathrm{z}$ art. 118a ustawy Pr. o szk. wyższ. możliwości zawarcia z nauczycielem akademickim umowy o pracę na czas określony oraz na czas nieokreślony. Na marginesie warto dodać, że choć z treści cytowanego przepisu można wywodzić o jego stosowaniu jedynie do uczelni publicznych, to wydaje się, że ratio legis tak sformułowanej normy odnosi się do związania z uczelnią publiczną samego postępowania konkursowego, a nie rodzajów umowy o pracę, które w jego wyniku będą stanowiły podstawę nawiązania stosunku pracy z nauczycielem akademickim. Dyferencjacja w odniesieniu do charakteru uczelni będzie mieć w tym zakresie wymiar indyferentny.

W poprzednio obowiązującym stanie prawnym, wyznaczanym normą art. $25 \mathrm{kp}$, jednym $\mathrm{z}$ rodzajów terminowej umowy o pracę była umowa na czas wykonania określonej pracy. Możliwość jej zawarcia z nauczycielem akademickim, choć niewyrażona expressis verbis, była przyjmowana $\mathrm{w}$ doktrynie ${ }^{13}$, nadto przewidywały ją statuty poszczególnych uczelni ${ }^{14}$. Tego rodzaju teza wynikała zapewne z konstrukcji przepisu art. 118a ust. 4 ustawy Pr. o szk. wyższ., który normując możliwość odstąpienia od procedury konkursowej, stanowił o umowie na czas określony nauczyciela akademickiego: skierowanego do pracy na uczelni na podstawie umowy zawartej z zagraniczną instytucją naukową; będącego beneficjentem krajowego konkursu ogłoszonego przez Narodowe Centrum Nauki lub Narodowe Centrum Badań i Rozwoju lub międzynarodowego konkursu na realizację projektu badawczego związanego z obszarem kształcenia; zatrudnianego na czas realizacji projektu finansowanego ze środków pochodzących z Unii Europejskiej lub przez inny podmiot przyznający grant. Zdefiniowanie celu, dla którego określano czas trwania umowy o pracę, oraz związanie tego czasu z wykonywaniem określonych czynności przez nauczyciela akademickiego czyniło w istocie zadość definicyjnym uwarunkowaniom umowy o pracę na czas wykonania określonej pracy. Po nowelizacji kp, która weszła w życie 22 lutego 2016 r., tego rodzaju umowa o pracę już nie jest częścią katalogu, przewidzianego w art. $25 \mathrm{kp}$, a co za tym idzie, nieuzasadniona staje się typizacja umowy o pracę na czas wykonania określonej pracy w jakimkolwiek wymiarze normatywnym, chyba że regulacja pragmatyczna wprost stworzy tego typu konstrukcję dla użytku partykularnego. De lege lata przepis art. 118a ust. 4 ustawy Pr. o szk. wyższ., w wyżej przywołanym zakresie, należy traktować jedynie jako wyjątek od zasady postępowania konkursowego, prowadzącego do nawiązania stosunku pracy z nauczycielem akademickim, a nie jako podstawę do wyodrębniania innego rodzaju umowy o pracę niż umowy na czas określony i nieokreślony. Tego typu wnioskowanie

${ }_{12}$ Por. W Sanetra, w: Prawo o szkolnictwie wyższym. Komentarz, W. Sanetra, M. Wierzbowski (red.), Warszawa 2013, s. 263.

13 T. Kuczyński, Komentarz do art. 118..., s. 73.

${ }^{14}$ Por. według stanu na dzień 1 stycznia 2015 r. \$89 ust. 4 statutu Uniwersytetu Warszawskiego, zgodnie z którym nauczyciel akademicki jest zatrudniany na podstawie umowy o pracę na czas określony, czas wykonania określonej pracy lub na czas nieokreślony; $\$ 93$ statutu Uniwersytetu Wrocławskiego, w myśl którego zatrudnienie nauczyciela akademickiego w związku z realizacją projektu badawczego finansowanego ze środków pozabudżetowych następuje na podstawie umowy na czas wykonywania określonej pracy. 
implikuje także konieczność podjęcia stosownych działań przez uprawnione organy uczelni w celu dostosowania regulacji statutowych do obowiązującego katalogu rodzajów umowy o pracę.

W związku z przyjętą tezą o enumeratywnym katalogu umów o pracę, które mogą być zawarte z nauczycielem akademickim, zgodnie z art. 118 i 118a ustawy Pr. o szk. wyższ., a tym samym partykularnym charakterze regulacji samej ustawy w tym zakresie, zarówno w okresie sprzed nowelizacji kp z 2016 r., jak i obecnie ze wszech miar uzasadniony jest wniosek o niedopuszczalności stosowania do kontraktowego zatrudnienia nauczyciela akademickiego umowy o pracę na okres próbny. Jako że celem tej umowy nie jest osiągniecie gospodarczego rezultatu zatrudnienia w sposób właściwy dla pozostałych umów, ale sprawdzenie pracownika na zajmowanym stanowisku i zapewnienie automatycznego rozwiązania tej umowy w razie niepomyślnego wyniku próby ${ }^{15}$, to niedopuszczalność zawarcia tej umowy z nauczycielem akademickim uzasadniają także względy funkcjonalne, odnoszące się do maksymalnego 3-miesięcznego okresu trwania tego typu umowy oraz wymiary temporalne semestru studiów czy roku akademickiego, stanowiące w istocie element konstrukcji obciążeń dydaktycznych, naukowych i organizacyjnych nauczyciela akademickiego.

W okresie obowiązywania normy art. $25 \mathrm{kp} \mathrm{w}$ brzmieniu sprzed nowelizacji z $2016 \mathrm{r}$. za problematyczne i wątpliwe uznawano zawarcie z nauczycielem akademickim umowy o pracę na zastępstwo, formułując tezę, że stanowi ona w istocie odrębny rodzaj umowy o pracę, nieprzewidziany w dyspozycji normy art. 118a ustawy Pr. o szk. wyższ. Zwracano jednak już wówczas uwagę, że umowa ta wykazuje wiele swoistości ${ }^{16}$, co, biorąc nadto pod uwagę cel i przeznaczenie tej umowy, czas jej trwania oraz miejsce i w systemie przepisów, uzasadniało tezę, że jest ona w istocie zmodyfikowaną postacią umowy o pracę na czas określony ${ }^{17}$. Już wówczas także argumentem przemawiającym za odrzuceniem koncepcji odrębności typologicznej umowy na zastępstwo było samo ujęcie normatywne, odwołujące się do konstrukcji umowy na czas określony, zawartej jedynie w okolicznościach nieobecności pracownika z uzasadnionych przyczyn. Powyższe uzasadniało wniosek o dopuszczalności stosowania umowy na zastępstwo jako podstawy nawiązania stosunku pracy z nauczycielem akademickim. De lege lata instytucjonalne związanie umowy na zastępstwo z rodzajem umowy o pracę na czas określony jest jeszcze bardziej oczywiste. Zgodnie bowiem z treścią art. $25^{1} \S 4$ pkt $1 \mathrm{kp}$ zawarcie umowy w celu zastępstwa pracownika w czasie jego usprawiedliwionej nieobecności w pracy stanowi okoliczność przekroczenia maksymalnego czasu albo maksymalnej liczby umów na czas określony. Można zatem stwierdzić, że nie istnieją w chwili obecnej żadne normatywne przesłanki do traktowania umowy o pracę na zastępstwo jako odrębnego od innych typów rodzaju umowy o pracę. Wobec powyższego, biorąc pod uwagę dopuszczalność stosowania umowy na czas określony w zakresie zatrudnienia nauczyciela akademickiego,

${ }^{15}$ Por. wyrok SN z dnia 4 września 2013 r., II PK 358/12, LEX, nr 1460947.

16 W. Sanetra, w: Prawo o szkolnictwie..., s. 263.

17 T. Kuczyński, Komentarz do art. 118..., s. 74. 
traktując jednocześnie okoliczność zastępstwa pracownika nieobecnego jako jedynie warunki zawarcia tego rodzaju umowy, nie budzi żadnych wątpliwości możliwość stosowania tego rodzaju konstrukcji w stosunku do nauczyciela akademickiego. Jedyną wątpliwością, która istniała przed nowelizacją kp z 2016 r. i zachowuje aktualność także i w chwili obecnej, jest problem konieczności stosowania przy zawieraniu takiej umowy procedury konkursowej, w rozumieniu art. 118a ustawy Pr. o szk. wyższ. Z jednej strony bowiem względy celowościowe i funkcjonalne przemawiają za odstąpieniem od tej procedury także wtedy, gdy zatrudnienie ma przewyższać połowę etatu (co w praktyce będzie występowało najczęściej), a z drugiej strony, wykładnia tekstualna art. 118 a ust. 4 ustawy Pr. o szk. wyższ., formułującego enumeratywny katalog okoliczności, w których pomięcie procedury konkursowej jest możliwe, niezawierającego przypadku zastępstwa nieobecnego pracownika, prowadzi do wniosku, że zachowanie tej procedury jest konieczne. I nie zmienia tego wniosku podnoszona w doktrynie okoliczność, że aktualne brzmienie art. 25 i $25^{1} \mathrm{kp}$ podkreśla odrębność umowy na zastępstwo wobec zwykłych umów terminowych. Taki stan rzeczy może zmienić jedynie interwencja ustawodawcy.

Reasumując dotychczasowe rozważania w zakresie rodzajów umowy o pracę, stanowiących podstawę nawiązania stosunku pracy z nauczycielem akademickim, wypada skonstatować, że problematyka ta stanowi treść pragmatycznych norm ustawy Pr. o szk. wyższ., regulujących ten zakres stosunku pracy w szkole wyższej w sposób autonomiczny w odniesieniu do przepisów kp.

Kolejnym problemem, który jawi się jako istotny w kontekście zatrudnienia nauczyciela akademickiego na podstawie umowy o pracę i wymaga rozstrzygnięcia w odniesieniu do kolizji norm kp i ustawy Pr. o szk. wyższ., jest zagadnienie maksymalnego czasu trwania umowy o pracę na czas określony, a w związku z tym obowiązku bezterminowości stosunku pracy. Problem jest tym bardziej aktualny, gdy weźmie się pod uwagę nowe regulacje kp w tym zakresie, które w odróżnieniu od poprzednio obowiązującego stanu prawnego posługują się czytelnymi normami, zawierającymi wymierne faktory liczby umów oraz maksymalnego czasu ich trwania.

Niezbędnym zabiegiem, który musi poprzedzić analizę przedstawionego problemu, jest odpowiedź na pytanie, czy podobnie, jak to ma miejsce w odniesieniu do rodzajów umów o pracę, ustawa Pr. o szk. wyższ. przewiduje normy znajdujące zastosowanie $\mathrm{w}$ miejsce art. $25^{1} \mathrm{kp}$, czy też konieczny będzie mechanizm posiłkowego stosowania przepisów kp na podstawie odesłania $\mathrm{z}$ art. 136 ust. 1 ustawy Pr. o szk. wyższ. Biorąc pod uwagę dyspozycję norm ustawowych, które na zasadzie art. 5 kp mogłyby znaleźć zastosowanie w kontekście maksymalnego czasu zatrudnienia terminowego nauczyciela akademickiego, zasadne jawi się przywołanie w tym miejscu dwóch przepisów ustawy Pr. o szk. wyższ.

Zgodnie $\mathrm{z}$ art. $118 \mathrm{a}$ ust. 4 pkt 4 brak jest konieczności stosowania procedury konkursowej przy nawiązaniu stosunku pracy nauczyciela akademickiego na podstawie umowy na czas określony w przypadku, w którym zatrudnienie, następujące na to samo stanowisko, było poprzedzone poprzednim, trwającym nie krócej niż 3 lata. Tego rodzaju mechanizm kontynuacji zatrudnienia jest istotny w analizowanym kontekście, biorąc 
bowiem pod uwagę wynikający z kp maksymalny 33-miesięczny czas trwania jednej albo nie więcej niż trzech umów o pracę na czas określony, można byłoby odnieść wrażenie, że przywołany przepis ustawy Pr. o szk. wyższ. ma charakter lex specialis w stosunku do art. $25^{1} \mathrm{kp}$, a przez to wyłączy stosowanie normy kp w myśl dyrektywy lex specialis derogat legi generali. Nie wydaje się jednak, aby tego rodzaju wnioskowanie było uzasadnione. Art. 118a ustawy Pr. o szk. wyższ. dotyczy innego zakresu odniesienia, normuje bowiem w przedmiotowym zakresie procedurę konkursową przy „pierwszorazowym” zatrudnieniu, niezależnie od podstawy nawiązania stosunku pracy. Owszem, z wyjątku od procedury konkursowej, o którym mowa w art. 118a ust. 4 pkt 4, można wnosić, że ponowne zatrudnienie na podstawie umowy o pracę na czas określony nauczyciela akademickiego, który uprzednio był już zatrudniony na okres nie krótszy niż 3 lata, wykraczające poza maksymalny czas przyjęty w kp, to zabieg normatywny, którego przedmiotem jest sformułowanie patrykularnych zasad obowiązujących w szkołach wyższych, a przez to wyłączających stosowanie art. $25^{1} \mathrm{kp}$. Tego rodzaju teza stoi jednak w wyraźnej opozycji w stosunku do dyrektywy interpretacyjnej idem dixit quam voluit. Co więcej, można wyobrazić sobie także sytuację, w której podstawą poprzedniego zatrudnienia nauczyciela akademickiego, w stosunku do którego odstąpi się od procedury konkursowej, wcale nie była umowa o pracę na czas określony, ale bezterminowa umowa o pracę, która została rozwiązana na podstawie porozumienia stron albo jednostronnego oświadczenia choćby o wypowiedzeniu stosunku pracy, a następnie z takich czy innych powodów strony postanowiły o ponownym nawiązaniu stosunku pracy na podstawie umowy o pracę na czas określony. Zasadność tak sformułowanej tezy zdaje się potwierdzać także fakt, że norma art. 118a ust. 4 pkt 4 w żaden sposób nie odnosi się do ewentualnych przerw w zatrudnieniu tego nauczyciela akademickiego, a wobec tego kolejne zatrudnienie na podstawie umowy o pracę na czas określony może nastąpić także i po okresie, w którym strony nie są związane stosunkiem pracy.

Drugą normą ustawy Pr. o szk. wyższ., która wymaga analizy w kontekście ewentualnego wyłączenia stosowania art. $25^{1} \mathrm{kp}$, jest art. 120, który reguluje zagadnienie maksymalnych okresów zatrudnienia na stanowiskach asystenta czy adiunkta bez uzyskania odpowiedniego stopnia naukowego. Zgodnie z tym przepisem okres zatrudnienia na stanowisku asystenta osoby nieposiadającej stopnia naukowego doktora oraz okres zatrudnienia na stanowisku adiunkta osoby nieposiadającej stopnia naukowego doktora habilitowanego, a także warunki skracania i przedłużania oraz zawieszania tych okresów określa statut, z tym że zatrudnienie na każdym z tych stanowisk osoby nieposiadającej stopnia naukowego doktora lub doktora habilitowanego nie może trwać dłużej niż osiem lat ${ }^{18}$. Z argumentu lege non distinguente można wywieść, że cytowany

${ }^{18}$ W brzmieniu obowiązującym od 1 października $2013 \mathrm{r}$. W poprzednim brzmieniu, obowiązującym do 1 września 2006 r., przepis tworzył delegację do regulacji statutowej, bez ograniczenia maksymalnym 8-letnim okresem zatrudnienia. Zmianę można odczytywać jako swoiste ograniczenie autonomii uczelni. Co istotne, począwszy od 1 października 2013 r., wszystkie maksymalne okresy zatrudnienia na stanowisku asystenta lub adiunkta bez uzyskania odpowiedniego stopnia naukowego należy liczyć od początku. 
przepis znajduje zastosowanie zarówno do uczelni publicznych, jak i niepublicznych ${ }^{19}$. Ustawodawca nie określa sankcji za przekroczenie maksymalnego okresu zatrudnienia na wskazanym w przepisie stanowisku osoby bez właściwego stopnia naukowego. Nie powinno jednak budzić wątpliwości, że dalsze trwanie takiego stosunku pracy można oceniać jako niezgodne z normą ustawy Pr. o szk. wyższ.

Analizując funkcję normy przywołanego przepisu, można przede wszystkim przytoczyć fragment uzasadnienia wyroku SN, w myśl którego „okresy zatrudnienia na stanowiskach asystenta (i odpowiednio - adiunkta) są ustanawiane w celu mobilizacji pracownika uczelni do rozwoju naukowego, wyrażającego się w uzyskiwaniu stopni ${ }^{20}$. Brak postępu w rozwoju naukowym przez czas określony w statucie może w konsekwencji uzasadniać rozwiązanie stosunku pracy" ${ }^{21}$. Pogląd ten zasługuje na aprobatę, zarówno w części odnoszącej się do uzasadnienia normy, jak i określenia sankcji z tytułu jej naruszenia.

Abstrahując jednak od funkcji analizowanej normy, a biorąc pod uwagę względy temporalne, maksymalny 8-letni okres zatrudnienia nauczyciela akademickiego na określonym stanowisku, bez uzyskania wymaganego stopnia naukowego, można prima facie traktować jako mechanizm pragmatycznego uregulowania materii tożsamej z art. $25^{1} \mathrm{kp}$, a przez to sformułować tezę o odrębnej regulacji i braku podstaw do stosowania norm kp przez odesłanie z art. 136 ust. 1 ustawy Pr. o szk. wyższ. Co najmniej dwa argumenty zdają się wykluczać tego typu wnioskowanie. Po pierwsze, zakres przedmiotowy art. 120 ustawy Pr. o szk. wyższ. jest precyzyjnie określony i obejmuje jedynie tych nauczycieli akademickich, którzy zajmują stanowiska asystenta bez posiadania stopnia naukowego doktora oraz są zatrudnieni na stanowisku adiunkta, nie legitymując się stopniem naukowym doktora habilitowanego. Nie ma żadnych normatywnych podstaw do poszerzania tak określonego zakresu podmiotowego tego przepisu, $w$ tym także na drodze regulacji statutowej ${ }^{22}$. W konsekwencji, gdyby założyć, że art. 120 ustawy Pr. o szk. wyższ. zastępuje normę art. $25^{1} \mathrm{kp}$, doszłoby do takiej sytuacji, w której w stosunku do części nauczycieli akademickich w zakresie maksymalnego czasu trwania umowy o pracę na czas określony stosowany jest mechanizm kodeksowy, a w stosunku do pozostałej jest on wyłączony i zastąpiony regulacją art. 120 ustawy Pr. o szk. wyższ. Tego rodzaju różnicowanie byłoby nie tylko pozbawione logiki, ale nadto można byłoby je traktować jako bezzasadne i bezprawne, bo tworzące dla sporej części nauczycieli akademickich, podlegających regulacji art. 120 ustawy Pr. o szk. wyższ., sytuację mniej korzystną w porównaniu $\mathrm{z}$ wymogiem bezterminowości stosunku pracy po 33 miesiącach na podstawie kp. Z ratio legis analizowanego przepisu wynika jednoznacznie, że w sytuacji przekroczenia maksymalnych okresów zatrudnienia na określonych stanowiskach, bez uzyskania odpowiedniego stopnia naukowego, właściwemu organowi szkoły wyższej

19 Tak W. Sanetra, w: Prawo o szkolnictwie..., s. 265.

20 Zob. U. Jackowiak, Problemy stabilności zatrudnienia asystentów i adiunktów szkót wyższych, Praca i Zabezpieczenie Społeczne 1987, 7, s. 16 i n.

${ }^{21}$ Zob. wyrok SN z dnia 4 kwietnia 2008 r., I PK 249/2007, Lex Polonica, nr 1958365.

${ }^{22}$ Por. wyrok SN z dnia 19 marca 2008 r., I PK 263/07, Lex Polonica, nr 3051038. 
przysługuje uprawnienie do rozwiązania stosunku pracy i bez znaczenia jest wówczas okoliczność, jaki typ kontraktu łączy strony. Przekroczenie okresu zatrudnienia w trybie art. 120 ustawy Pr. o szk. wyższ. i statutu, w odniesieniu do nauczyciela zatrudnionego na podstawie umowy o pracę na czas nieokreślony, może być bowiem traktowane jako okoliczność uzasadniająca wypowiedzenie tej umowy w rozumieniu art. $45 \mathrm{kp}$. Drugim argumentem, który przemawia za odrzuceniem tezy o możliwości stosowania art. 120 ustawy Pr. o szk. wyższ. w miejsce ogólnych reguł kodeksowych, określających maksymalny czas trwania umowy na czas określony oraz wymóg bezterminowości stosunku pracy, jest delegacja do regulacji statutowej, którą zawiera przedmiotowy przepis ustawy Pr. o szk. wyższ. Wskazany w analizowanej normie 8-letni okres zatrudnienia ma charakter maksymalny, ale jego określenie w stosunku do nauczycieli akademickich zatrudnionych w danej szkole wyższej to materia regulacji jej statutu. Nietrudno sobie zatem wyobrazić, że na poszczególnych uczelniach te okresy mogą się różnić, mieszcząc się jednocześnie w zakresie ustawowego maksimum. W odniesieniu zatem do maksymalnego czasu trwania stosunku pracy asystenta nieposiadającego stopnia naukowego doktora oraz adiunkta nieposiadającego stopnia naukowego doktora habilitowanego art. 120 ustawy Pr. o szk. wyższ. nie tworzy mechanizmu uniformizującego, a jednie określa granicę maksymalnego czasu trwania takich stosunków pracy, który uczelnie $\mathrm{w}$ ramach swojej autonomii precyzują w statutach.

Powyższe wywody uzasadniają odrzucenie tezy o istnieniu w ustawie Pr. o szk. wyższ. regulacji, które uniemożliwiałby stosowanie do nauczycieli akademickich art. $25^{1} \mathrm{kp}$ w zakresie maksymalnej liczby i maksymalnego czasu trwania stosunku pracy, nawiązanego na podstawie umowy o pracę na czas określony. Zarówno norma art. 118a ust. 4 pkt 4, jak i art. 120 ustawy Pr. o szk. wyższ. nie tylko nie wykazują walorów przepisów odpowiednich w stosunku do art. $25^{1} \mathrm{kp}$, lecz także ich brzmienie nie spełnia wymogów zastępowania, choćby w najogólniejszy sposób, instytucji kp. Tego rodzaju wnioski prowadzą do przyjęcia tezy o stosowaniu wobec nauczycieli akademickich zatrudnionych na podstawie umowy o pracę normy art. $25^{1} \mathrm{kp}$, na podstawie odesłania $\mathrm{z}$ art. 136 ust. 1 ustawy Pr. o szk. wyższ.

Zgodnie zatem $\mathrm{z}$ art. $25^{1} \$ 1 \mathrm{kp}$ okres zatrudnienia na podstawie umowy o pracę na czas określony, a także łączny okres zatrudnienia na podstawie umów o pracę na czas określony zawieranych między nauczycielem akademickim a uczelnią, nie może przekraczać 33 miesięcy, a łączna liczba tych umów nie może przekraczać trzech. W przypadku przekroczenia liczby umów na czas określony albo ich maksymalnego czasu trwania, zgodnie z dyspozycją art. $25^{1} \S 3 \mathrm{kp}$ nauczyciel akademicki, odpowiednio od dnia następującego po upływie 33 miesięcy lub od dnia zawarcia czwartej umowy o pracę na czas określony, jest zatrudniony na podstawie umowy o pracę na czas nieokreślony. Zgodnie z normą o charakterze intertemporalnym, zawartą $\mathrm{w}$ art. 14 ust. 4 ustawy nowelizującej przepisy kp od dnia 22 lutego 2016 r., do umów o pracę na czas określony, trwających w dniu wejścia w życie nowelizacji, stosuje się art. $25^{1}$ w zmienionym brzmieniu, jednakże do okresu zatrudnienia, o którym mowa w tym przepisie, wlicza się okres zatrudnienia na podstawie umowy o pracę na czas określony 
przypadający od dnia wejścia w życie niniejszej ustawy, a trwająca w tym dniu umowa o pracę na czas określony jest uważana za pierwszą albo za drugą umowę, jeżeli została zawarta jako druga umowa, w rozumieniu sekwencyjności umów w poprzednio obowiązującym brzmieniu art. $25^{1} \mathrm{kp}$. Co istotne, kodeksowy mechanizm określający maksymalną liczbę umów na czas określony albo czas ich trwania przewiduje wyjątki, w ramach których dopuszczalne będzie przekroczenie określonych w nim ograniczeń w sytuacjach wskazanych w art. $25^{1} \S 4 \mathrm{kp}$. Pomijając okoliczności umów na czas określony zawieranych w celu wykonywania prac o charakterze dorywczym lub sezonowym oraz $\mathrm{w}$ celu wykonywania pracy przez okres kadencji, jako indyferentnych z punktu widzenia problematyki niniejszego opracowania, pozostałe dwa wyjątki wymagają szerszego omówienia w kontekście terminowego zatrudnienia nauczyciela akademickiego.

Zgodnie $\mathrm{z}$ art. $25^{1} \S 4$ pkt 1 umowa na czas określony może być zawarta $\mathrm{z}$ pominięciem ograniczeń liczby i czasu trwania umów, wówczas gdy zawiera się ją w celu zastępstwa pracownika w czasie jego usprawiedliwionej nieobecności w pracy. Tego rodzaju konstrukcja normatywna odnosi się w istocie do umowy na zastępstwo jako umowy na czas określony, zwieranej w szczególnych, zdefiniowanych okolicznościach i de lege lata nie powinno budzić już żadnych wątpliwości to, że umowa na zastępstwo nie jest odrębnym rodzajem umowy o pracę. Nawiązując do wyżej poczynionych uwag w zakresie dopuszczalności zwarcia takiej umowy z nauczycielem akademickim, zarówno w poprzednio obowiązującym stanie prawnym, jak i aktualnie, wypada w tym miejscu dodać, że zawarcie umowy o pracę na czas określony z nauczycielem akademickim, w okolicznościach zastępstwa innego nauczyciela akademickiego, nieobecnego $\mathrm{z}$ usprawiedliwionych przyczyn, nie musi uwzględniać ograniczeń $\mathrm{z}$ art. $25^{1} \$ 1 \mathrm{kp}$. Kodeksowa regulacja określająca przypadki dopuszczalności zawarcia umowy na czas określony z pomięciem przepisu art. $25^{1} \$ 1 \mathrm{kp}$ wymaga nadto, aby zawarcie takiej umowy w danym przypadku służyło zaspokojeniu rzeczywistego okresowego zapotrzebowania i było niezbędne w tym zakresie w świetle wszystkich okoliczności zawarcia umowy. Odnosząc tego typu zastrzeżenie do umowy zawieranej w okolicznościach zastępstwa, chodzi o to, aby istniała faktyczna konieczność zastępstwa pracownika nieobecnego, a samo zatrudnienie osoby zastępującej nie miało charakteru czynności pozornej. W sferze szkolnictwa wyższego tak sformułowane wnioski będą się odnosić do rozważenia konieczności zatrudnienia nauczyciela akademickiego na zastępstwo w kontekście ewentualnych możliwości przekazania obowiązków dydaktycznych, naukowych i organizacyjnych, które miał wykonywać pracownik nieobecny, innym, już zatrudnionym osobom. Istotne znaczenie będzie mieć także wymóg zapewnienia tak zwanego minimum kadrowego oraz konieczności osobistego prowadzenia zajęć dydaktycznych przez nauczycieli akademickich, wchodzących w jego skład, w rozumieniu przepisów rozporządzenia Ministra Nauki i Szkolnictwa Wyższego z dnia 26 września 2016 r. w sprawie warunków prowadzenia studiów ${ }^{23}$.

${ }^{23}$ Dz. U. z 2016 r., poz. 1596. 
Drugi, istotny dla zatrudnienia nauczyciela akademickiego, wyjątek od zasady maksymalnej liczby umów na czas określony oraz czasu ich trwania, wprowadza art. $25^{1} \S$ pkt $4 \mathrm{kp}$. Zgodnie $\mathrm{z}$ tym przepisem jest to możliwe w przypadkach, gdy pracodawca wskaże obiektywne przyczyny leżące po jego stronie i podobnie jak w przypadku umowy w okolicznościach zastępstwa zawarcie umowy w danym wypadku służy zaspokojeniu rzeczywistego okresowego zapotrzebowania i jest niezbędne w tym zakresie w świetle wszystkich okoliczności zawarcia umowy. Użycie przez ustawodawcę sformułowania „obiektywnych przyczyn”, uzasadniających odstąpienie od mechanizmu art. $25^{1} \$ 1 \mathrm{kp}$, to w istocie posłużenie się przez niego klauzulą generalną, która będzie wymagać, aby w indywidualnych okolicznościach wypełnić ją konkretną treścią. Na marginesie można się zastanawiać, czy wprowadzenie takiego mechanizmu legislacyjnego w ramach regulacji gwarantującej bezterminowość stosunku pracy było słusznym wyborem ustawodawcy i czy niechęć pracodawców do zawierania umowy o pracę na czas nieokreślony nie spowoduje, że właśnie w tym zakresie będą szukać, często nadużywając analizowanej regulacji, możliwości długotrwałego zatrudnienia na podstawie umowy o pracę na czas określony.

Działając na zasadzie odesłania z art. 136 ust. 1 ustawy Pr. o szk. wyższ. i przenosząc treść normy art. $25^{1} \$ 4$ pkt $4 \mathrm{kp}$ na zatrudnienie w szkołach wyższych, warto zastanowić się, w jakich konkretnych przypadkach możliwe będzie zawarcie umowy o pracę z nauczycielem akademickim na czas określony, wykraczające poza ramy liczbowe i czasowe określone w kp. W moim przekonaniu sytuacje takie mogą mieć zarówno źródło ustawowe, jak i wynikające ze specyfiki zatrudnienia na uczelni. Odnosząc się do tych drugich, można w ramach egzemplifikacji dopuścić zatrudnienie nauczyciela akademickiego na podstawie umowy o pracę na czas określony, zawartej na okres 36 miesięcy. Funkcjonowanie uczelni, a co za tym idzie określanie obowiązków nauczycieli akademickich w sferze dydaktyki, nauki i spraw organizacyjnych, wyznacza sekwencja lat akademickich. Przepisy ustawy Pr. o szk. wyższ. nie określają granic czasowych roku akademickiego, zgodnie natomiast z art. 160 ust. 1 ustawy Pr. o szk. wyższ. organizację i tok studiów oraz związane z nimi prawa i obowiązki studenta określa regulamin studiów. Moc wiążąca regulaminu w sprawach, które reguluje, nie budzi wątpliwości ${ }^{24}$, a zapisy odnośnie do organizacji roku akademickiego mogą dotyczyć także spraw pracowniczych. Analiza regulaminów studiów szkół wyższych prowadzi do wniosku o jednolitym charakterze ich norm, określających granice czasowe roku akademickiego, który ma się rozpoczynać 1 października i kończyć 30 września kolejnego roku kalendarzowego, choć i w tym zakresie zdarzają się wyjątki ${ }^{25}$. Zasadą jest zatem, że rok akademicki, jak i rok kalendarzowy, trwa 12 miesięcy. Biorąc pod uwagę względy funkcjonalne, a także wymogi w zakresie wspomnianego wyżej minimum kadrowego, można założyć, iż czas trwania umowy na czas określony, zawartej z nauczycielem akademickim, będzie obejmował rok

${ }^{24}$ Zob. wyrok WSA w Gdańsku z dnia 24 lutego 2011, III SA/Gd 377/10, Legalis, nr 328550.

${ }^{25} \mathrm{~W}$ niektórych regulaminach studiów rok akademiki trwa od 1 września do 31 sierpnia następnego roku kalendarzowego. 
akademicki albo jego wielokrotność. Odnosząc wobec tego maksymalny 33-miesięczny okres zatrudnienia na czas określony do specyfiki działania uczelni, wypada przyjąć, że przedłużenie umowy o pracę zawartej z nauczycielem akademickim na czas 3 lat akademickich, czyli 36 miesięcy, będzie wypełniało klauzulę generalną obiektywnych przyczyn, leżących po stronie pracodawcy, będzie także służyło zaspokojeniu rzeczywistego okresowego zapotrzebowania i wypełni przesłankę niezbędności w świetle wszystkich okoliczności zawarcia takiej umowy.

W poszukiwaniu ustawowych źródeł przypadków, w których w stosunku do nauczyciela akademickiego możliwe będzie zastosowanie mechanizmu art. $25^{1} \$ 4$ pkt $4 \mathrm{kp}$, wystarczające jawi się nawiązanie w tym miejscu do poczynionych wyżej rozważań na temat norm art. 118a oraz art. 120 ustawy Pr. o szk. wyższ.

Zgodnie z art. 118a ust. 4 ustawy Pr o szk. wyższ. wyłączenie procedury konkursowej przy zatrudnianiu nauczyciela akademickiego jest możliwe w kilku przypadkach, poza analizowaną wyżej kontynuacją stosunku pracy, po poprzednim zatrudnieniu trwającym nie krócej niż 3 lata. Po pierwsze, chodzi tu o nauczyciela akademickiego skierowanego do pracy na uczelni na podstawie umowy zawartej z zagraniczną instytucją naukową. Po drugie, w sytuacji, kiedy jest on beneficjentem krajowego konkursu ogłoszonego przez Narodowe Centrum Nauki lub Narodowe Centrum Badań i Rozwoju lub międzynarodowego konkursu na realizację projektu badawczego związanego z obszarem kształcenia. Po trzecie wreszcie, w przypadku zatrudnienia go na czas realizacji projektu finansowanego ze środków pochodzących z Unii Europejskiej albo przekazanych przez inny podmiot przyznający grant. Pomijając zasadniczy cel normy art. 118a ustawy Pr. o szk. wyższ., jakim bez wątpienia jest regulacja trybu nawiązania stosunku pracy z nauczycielem akademickim, wydaje się, że przywołane stany faktyczne mogą stanowić także okoliczności, w których zatrudnienie na czas określony może odbywać się na zasadzie wyjątku od reguł zatrudnienia terminowego, zawartych $\mathrm{w}$ art. $25^{1} \$ 1 \mathrm{kp}$. Nie ulega bowiem wątpliwości, że zarówno skierowanie do pracy, wynikające z umowy łączącej uczelnię z zagraniczną instytucją naukową, jak i kontrakt stanowiący następstwo konkursu lub realizację projektu, bez względu na źródło jego finansowania, nie musi ograniczać się do 33 miesięcy. Zawarcie w takich okolicznościach z nauczycielem akademickim dłuższej umowy o pracę na czas określony albo czwartej i kolejnej takiej umowy będzie mieściło się w dyspozycji normy art. $25^{1} \S 4$ pkt $4 \mathrm{kp}$, stanowiąc obiektywną przyczynę leżącą po stronie pracodawcy. W kontekście realizacji projektów albo umowy z zagraniczną instytucją naukową, ograniczonych określonym w nich terminem realizacji, będzie ponadto służyło zaspokajaniu rzeczywistych, okresowych potrzeb pracodawcy. Istotne znaczenie ma w tym miejscu także nawiązanie do niewystępującej już aktualnie umowy o pracę na czas wykonania określonej pracy. Wydaje się, że specyfika tej umowy została na gruncie przepisów kp wkomponowana w instytucję umowy o pracę na czas określony, a dokładnie w regulacje, umożliwiające odstępstwo od ograniczeń czasowych i liczbowych zawierania tej umowy z pracownikiem. Skoro zatem to właśnie okoliczności określone w art. 118a ust. 4 ustawy Pr. o szk. wyższ. były normatywną podstawą umożliwiającą $\mathrm{w}$ poprzednim stanie prawnym zawieranie $\mathrm{z}$ nauczycielem akademickim umowy o pracę na czas wykonywania określonej pracy, to 
można je de lege lata stosować jako wypełniające zakres przedmiotowy instytucji, która tę umowę w pewnym sensie zastąpiła.

Podobnie w kategoriach obiektywnej przyczyny, leżącej po stronie pracodawcy i służącej zaspokajaniu jego rzeczywistych potrzeb, należy traktować możliwość zawarcia umowy na czas określony na stanowisku asystenta osoby nieposiadającej stopnia naukowego doktora lub na stanowisku adiunkta osoby nieposiadającej stopnia naukowego doktora habilitowanego, gdzie czas trwania tej umowy będzie zsynchronizowany z maksymalnym okresem, wskazanym w statucie, na podstawie delegacji z art. 120 ustawy Pr. o szk. wyższ. I nie ma w tym kontekście znaczenia fakt, że okoliczność nieuzyskania określonego stopnia naukowego dotyczy w istocie pracownika i jego aktywności, a nie pracodawcy, bo treścią klauzuli generalnej z art. $25^{1} \$ 4$ pkt 4 kp będzie obowiązek pracodawcy zakończenia tego stosunku pracy i brak możliwości jego kontynuacji na określonym stanowisku.

Skorzystanie przez uczelnię z mechanizmu umożliwiającego zawarcie z nauczycielem akademickim umowy o pracę na czas określony, na warunkach określonych w art. $25^{1} \$ 4$ pkt $4 \mathrm{kp}$, będzie się łączyć z obowiązkiem informacyjnym, określonym w art. $25^{1} \$ 5 \mathrm{kp}$. Zgodnie z tym przepisem pracodawca zawiadamia właściwego okręgowego inspektora pracy, w formie pisemnej lub elektronicznej, o zawarciu takiej umowy o pracę, wraz ze wskazaniem przyczyn zawarcia takiej umowy, w terminie 5 dni roboczych od dnia jej zawarcia. Tego rodzaju konstrukcja, przewidująca weryfikację przez inspektora pracy konkretnych okoliczności, wskazanych przez pracodawcę, ma w założeniu stanowić podstawę do ograniczenia nadużyć zatrudnienia terminowego. Można jednak założyć, że w przypadku wskazania przez uczelnię okoliczności, o których mowa w art. 118a i art. 120 ustawy Pr. o szk. wyższ., zasadność zawarcia umowy na czas określony, stanowiącej odstępstwo od przewidzianych w kp limitów co do liczby takich umów oraz maksymalnego czasu ich trwania, nie powinna budzić wątpliwości.

\section{Umowa o pracę w sferze szkolnictwa wyższego de lege ferenda}

Formułowanie postulatów de lege ferenda, odnoszących się do zatrudnienia nauczyciela akademickiego na podstawie umowy o pracę, determinuje konieczność odwołania się także do instytucji mianowania jako drugiego aktu kreującego stosunek pracy nauczyciela akademickiego. Niezbędne będzie w tym miejscu także nawiązanie do toczącej się, w związku z projektem przyszłej ustawy o szkolnictwie wyższym, dyskusji na temat nowego modelu stanowisk nauczycieli akademickich, związanego z posiadaniem stopnia lub tytułu naukowego.

Jak już wyżej wspomniano, podstawą nawiązania stosunku pracy z nauczycielem akademickim może być umowa o pracę albo akt mianowania. Mianowanie w szkole wyższej jest instytucją, która w wymiarze historycznym ewoluowała w zakresie charakteru prawnego. Biorąc pod uwagę akty prawne obowiązujące od lat przedwojennych aż do lat 90. XX wieku, można skonstatować, że mianowanie (akt nominacji) było czynnością prawa publicznego, opartą na władczej roli państwa, same zaś stosunki pracy miały wyraźny 
charakter służbowy. Wydaje się, że dopiero na podstawie ustawy z dnia 16 września 1990 r. o szkolnictwie wyższym ${ }^{26}$ mianowanie nauczyciela akademickiego w znaczący sposób wykazywało cechy swoistej czynności prawnej z zakresu prawa pracy, tracącej swój wyraźny służbowy i administracyjno-prawny charakter. Na gruncie obowiązującej ustawy Pr. o szk. wyższ. akt nominacji nauczyciela akademickiego zdaje się instytucją dalece odmienną od służbowych stosunków pracy, brak bowiem w jego konstrukcji elementów stanowiących ich differentia specifica, takich jak choćby dyspozycyjność, wyrażająca się w możliwości dysponowania osobą pracownika poza granicami wyznaczonymi rodzajem pracy, a także wykonywanie czynności władczych. Nadto godzi się w tym miejscu zauważyć, że de lege lata stosowanie mianowania w szkole wyższej jest uzależnione od brzmienia przepisów statutowych, co nadaje temu aktowi kreującemu stosunek pracy wymiar fakultatywny ${ }^{27}$. Co więcej, zabiegi doktryny mające charakter porządkujący stosunki pracy oparte na mianowaniu poza sferą mundurową i wprowadzające w tym zakresie delimitację stosunków służbowo-pracowniczych (sędziowie i prokuratorzy), stosunków pracowniczo-służbowych (urzędnicy) oraz stosunków pracowniczych $\mathrm{z}$ elementami służby (nauczyciele i pracownicy nauki) ${ }^{28}$, mając uzasadnienie de lege lata, wydają się działaniem o charakterze tymczasowym. Wspomniane zawężenie aktu nominacji do nauczycieli akademickich posiadających tytuł naukowy w istotny sposób zmniejsza liczbę stosunków pracy w szkole wyższej opartych na mianowaniu. Konstrukcja przepisów przejściowych, nowelizujących ustawę Pr. o szk. wyższ. w 2011 r., niewprowadzających zasady przekształcenia wcześniej nawiązanych stosunków pracy na podstawie mianowania $\mathrm{w}$ stosunki pracy oparte na umowie o pracę, jedynie przesuwa w czasie moment, w którym akt mianowania będzie dotyczył zdecydowanej mniejszości nauczycieli akademickich.

Jeżeli dodać, że dyferencjacja stosunku pracy nauczyciela akademickiego, oparta na kryterium podstawy nawiązania stosunku pracy, jest $\mathrm{w}$ wielu aspektach pozorna, a w części pozbawiona racjonalnych kryteriów ${ }^{29}$, to postulat uniformizmu w analizowanym zakresie wydaje się jak najbardziej uzasadniony. Sądzę, że działanie ustawodawcy, coraz wyraźniej zbliżające stosunki pracy nauczycieli akademickich mianowanych oraz zatrudnionych na podstawie umowy o pracę, zmierza do wykluczenia aktów nominacji ze sfery szkolnictwa wyższego, czego zresztą byłem i jestem zwolennikiem ${ }^{30}$. Tego rodzaju mechanizmy

${ }^{26}$ Dz. U. z 1990 r., Nr 65, poz. 385, z późn. zm.

27 Tak J. Stelina, Przemiany stosunków pracy z mianowania, w: Wspótczesne problemy prawa pracy i ubezpieczeń społecznych, L. Florek, Ł. Pisarczyk (red.), Warszawa 2011, s. 97.

${ }_{28}$ Tak T. Kuczyński, w: System prawa administracyjnego, t. XI, Stosunek służbowy, R. Hauser, Z. Niewiadomski, A. Wróbel (red.), Warszawa 2011, s. 23-42.

29 Zob. M. Lekston, Dyferencjacja zatrudnienia w szkole wyższej. Analiza kryteriów, Studia z Zakresu Prawa Pracy i Polityki Społecznej 2010, s. 159-169.

${ }^{30}$ Por. M. Lekston, Wypowiedzenie stosunku pracy?; Tenże, Ciężkie naruszenie podstawowych obowiązków pracowniczych jako przyczyna rozwiązania stosunku pracy z nauczycielem akademickim, Studia z Zakresu Prawa Pracy i Polityki Społecznej 2012. 
wydają się potwierdzać prace zespołów ${ }^{31}$ przygotowujących projekty nowej ustawy o szkolnictwie wyższym, które po procesie zaplanowanych konsultacji mają doprowadzić do przyjęcia od 1 października 2018 r. nowych regulacji Prawa o szkolnictwie wyższym. Zgodnie z zaprezentowanymi przez zespoły założeniami w dwóch przypadkach jedyną podstawą nawiązania stosunku pracy z nauczycielem akademickim miałaby być umowa o pracę ${ }^{32}$, a tylko jeden przewiduje konstrukcję kontynuacji dualizmu aktu kreującego, zachowując obok umowy o pracę akt mianowania ${ }^{33}$. W przypadku rezygnacji w nowej ustawie z nominacyjnych stosunków pracy ważne jednak jest i to, aby zabieg ten był przemyślany w wymiarze intertemporalnym oraz wprowadzając konstrukcję uniformizmu samego aktu kreującego, uwzględniał różnice wewnątrz grupy pracowników zatrudnionych w charakterze nauczyciela akademickiego. Odnosząc się do przyszłej konstrukcji likwidacji nominacyjnych stosunków pracy, ustawodawca nie powinien podążać drogą, którą obrał w przypadku samorządowych stosunków pracy w 2012 r., poprzez mechanizm ich prostego zastąpienia bezterminową umową o pracę ${ }^{34}$. Opowiadam się w tym miejscu za konstrukcją przepisów przejściowych, które nie zmieniają aktu kreującego w przypadku stosunków pracy, uprzednio nawiązanych na podstawie mianowania, lecz utrzymują ten charakter do czasu ich wygaśnięcia lub rozwiązania na podstawie przepisów obowiązujących przed wejściem w życie nowych regulacji ${ }^{35}$. Nominacja bowiem de lege lata stanowi swego rodzaju wyróżnienie i rekompensatę z tytułu posiadanego tytułu naukowego, za którym stoi znaczący dorobek naukowy, dydaktyczny oraz pozycja w środowisku akademickim.

Gdy chodzi o umowę o pracę, która stałaby się jedynym aktem kreującym stosunki pracy z nauczycielami akademickimi, to postulowany uniformizm nie powinien się w mechaniczny sposób przekładać na kształt praw i obowiązków nauczycieli akademickich. Biorąc bowiem pod uwagę zróżnicowanie wewnętrzne w tej grupie zawodowej, wydaje

31 W ramach konkursu Ustawa 2.0., ogłoszonego przez Ministra Nauki i Szkolnictwa Wyższego, założenia oraz projekt nowej ustawy o szkolnictwie wyższym przygotowują: Zespół Uniwersytetu SWPS pod kierunkiem prof. dra hab. Huberta Izdebskiego, Zespół Uniwersytetu im. Adama Mickiewicza w Poznaniu pod kierunkiem prof. dra hab. Marka Kwieka oraz Zespół Instytutu Allerhanda pod kierunkiem prof. dra hab. Arkadiusza Radwana.

${ }^{32}$ Zob. Propozycja założeń do ustawy regulującej system szkolnictwa wyższego, H. Izdebski (red.), Warszawa 2017, s. 96; D. Kwiek, D. Antonowicz, J. Brdulak, M. Hulicka, T. Jędrzejewski, R. Kowalski, E. Kulczycki, K. Szadkowski, A. Szot, J. Wolszczak-Derlak, Projekt założeń do ustawy Prawo o szkolnictwie wyższym, Poznań 2016, s. 154.

${ }_{33}$ Zob. A. Radwan (red.), Plus ratio quam vis consetudinis. Reforma nauki i akademii w ustawie 2.0, Kraków 2017, s. 160.

${ }^{34}$ Zob. art. 54 ustawy z dnia 21 listopada 2008 r. o pracownikach samorządowych (Dz. U. z 2008 r., $\mathrm{Nr} 223$, poz. 1458 z późn. zm.), zgodnie z którym stosunek pracy osób zatrudnionych na podstawie mianowania na zasadach określonych $\mathrm{w}$ ustawie uchylanej $\mathrm{w}$ art. 60 przekształca się $\mathrm{z}$ dniem 1 stycznia 2012 r. w stosunek pracy na podstawie umowy o pracę na czas nieokreślony.

${ }^{35}$ Por. art. 22 ustawy z dnia 18 grudnia 1998 r. o pracownikach sądów i prokuratury (Dz. U., Nr 162, poz. 1125), zgodnie z którym stosunki pracy nawiązane przed dniem wejścia w życie ustawy na podstawie mianowania pozostają w mocy i mogą być zmieniane i rozwiązywane na zasadach określonych w ustawie o pracownikach urzędów państwowych. 
się, że tego typu jednolitość stosunków pracy, wynikająca z przepisów ustawowych, nie pełniłaby założeń właściwie rozumianej dyferencjacji prawa pracy. W ramach przepisów pragmatycznych należałoby przesunąć punkt ciężkości na aspekt organizacyjny, związany z zajmowanymi przez pracowników stanowiskami. Właśnie sfera organizacyjna biorąca za przedmiot kategorie nauczycieli akademickich oraz zajmowane przez nich stanowiska, implikująca przez to zakres ich obowiązków, powinna stać się dominującym faktorem kryterium różnicowania stosunku pracy. Założenia do nowej ustawy o szkolnictwie wyższym przedstawione przez wspomniane wyżej zespoły w różny sposób konstruują katalog stanowisk nauczycieli akademickich z określeniem ich charakteru oraz rygory selekcyjne umożliwiające zatrudnienie określonej osoby na danym stanowisku. Obok rozwiązań tożsamych $\mathrm{z}$ aktualnie obowiązującymi nie brak tam propozycji, które wprowadzają istotne modyfikacje w tym zakresie ${ }^{36}$. Przyjmując, że ostateczny kształt regulacji nowej ustawy w analizowanej części może jeszcze ewoluować w procesie legislacyjnym, abstrahując także od oceny propozycji zespołów, z zadowoleniem należy przyjąć fakt, że w przeważającej części projektowanych norm to właśnie stanowisko, na którym zatrudniony będzie nauczyciel akademicki, stanowi w ramach zaprezentowanych założeń decydujące kryterium różnicowania wewnątrz tej grupy zawodowej.

Odnośnie do rodzajów umowy o pracę, zaprezentowane rezultaty prac zespołów przewidują różne rozwiązania, symetryczne względem tego, czy byłaby to jedyna, czy nie, podstawa nawiązania stosunku pracy z nauczycielem akademickim. Zespoły, które prezentują pogląd rezygnacji z mianowania, opowiadają się za pragmatyczną regulacją w tym zakresie, konstruując mechanizm zawierania co do zasady umowy o pracę na

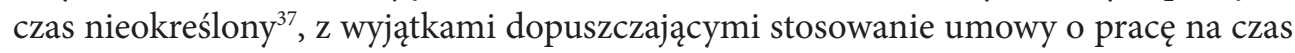
określony. Zespół, który postuluje dualizm podstawy nawiązania stosunku pracy, nie odnosi się wprost do katalogu umów o pracę z nauczycielem akademickim, ale wykładnia proponowanych przepisów, które w sposób aż nadto kazuistyczny regulują problem terminowych umów o pracę oraz kontynuacji zatrudnienia po określonym w umowie czasie ${ }^{38}$, prowadzi do wniosku, że umowa o pracę na czas nieokreślony nie byłaby podstawowym rodzajem kontraktu z nauczycielem akademickim. W przypadku publikacji jednego z zespołów pojawia się również konstrukcja umowy o pracę na czas wykonania określonej pracy w kontekście prac grantowych ${ }^{39}$. Wnosząc po odwołaniu się $\mathrm{w}$ treści założeń zaprezentowanych $\mathrm{w}$ tym kontekście do obowiązujących de lege lata konstrukcji art. 118a ust. 4 ustawy Pr. o szk. wyższ., sądzę, że propozycja tego rodzaju umowy, nieistniejącej już w katalogu kp, nie zmierzała do tworzenia norm oryginalnych, a opisana przeze mnie wyżej modyfikacja liczby i czasu trwania umowy

${ }^{36}$ Zob. A. Radwan (red.), Plus ratio quam vis consetudinis..., s. 156, gdzie proponuje się stanowiska doktora rezydującego, młodszego profesora czy profesora dydaktyki.

${ }^{37}$ Zob. Propozycja założeń..., s. 28; D. Kwiek, D. Antonowicz, J. Brdulak, M. Hulicka, T. Jędrzejewski, R. Kowalski, E. Kulczycki, K. Szadkowski, A. Szot, J. Wolszczak-Derlak, Projekt założén..., s. 154.

${ }_{38}$ A. Radwan (red.), Plus ratio quam vis consetudinis..., s. 156 i n.

39 Zob. Propozycja założeń..., s. 96. 
na czas określony na podstawie art. $25^{1} \$ 4 \mathrm{kp}, \mathrm{w}$ związku z art. 118a ust. 4 ustawy Pr. o szk. wyższ., czyniłaby zadość intencjom zespołu.

Biorąc pod uwagę przywołane fragmenty prac zespołów, opowiadam się w tym miejscu za przyjęciem konstrukcji, w której to umowa o pracę na czas nieokreślony byłaby zasadniczym rodzajem kontraktu zawieranego z nauczycielem akademickim. Tego rodzaju teza stanowi bowiem $\mathrm{w}$ istocie konsekwencję postulatu rezygnacji z nominacyjnych stosunków pracy z jednoczesną gwarancją przyjęcia mechanizmu uwzględniającego fundamentalną rolę, jaką w działaniu państwa odgrywa system szkolnictwa wyższego i nauczyciele akademiccy będący jego personifikacją. Stosowanie umowy o pracę na czas określony powinno zaś być możliwe w dwóch zakresach. Po pierwsze, w kontekście prac "grantowych” i projektowych, o których aktualnie mowa, w szczególności w art. 118a ust. 4 ustawy Pr. o szk. wyższ., po drugie zaś, na wzór obecnych w pragmatykach urzędniczych służby przygotowawczej ${ }^{40}$ albo stażu urzędniczego ${ }^{41}$, w ramach zatrudnienia na stanowiskach, które niezależnie od przyjętej koncepcji będą stanowiły pierwszy etap pracy dydaktycznej lub naukowo-dydaktycznej, a kontynuacja zatrudnienia, już na podstawie bezterminowej umowy o pracę, byłaby możliwa po uzyskaniu pozytywnej oceny w przyjętym trybie.

\section{Podsumowanie}

Analiza problemu zatrudnienia nauczyciela akademickiego na podstawie umowy o pracę wykazuje de lege lata konieczność stosowania w tym zakresie zarówno przepisów ustawy Pr. o szk. wyższ., które w pragmatyczny sposób określają przede wszystkim jej rodzaje, jak i norm kp, stosowanych na zasadzie odesłania z art. 136 ust. 1 ustawy Pr. o szk. wyższ., co szczególnie istotne w kontekście obowiązku zawarcia bezterminowej umowy o pracę po maksymalnym czasie trwania terminowych stosunków pracy. Wydaje się jednak, że specyfika zatrudnienia w sferze szkolnictwa wyższego powinna implikować regulację ustawową, która w sposób wyczerpujący określi zasady stosowania podstawy nawiązania stosunku pracy z nauczycielem akademickim. Słusznym rozwiązaniem wobec takiego założenia jest rezygnacja $z$ aktu nominacji dla nowo nawiązywanych stosunków pracy i pozostawienie właśnie umowy o pracę jako jedynego aktu kreującego w analizowanym zakresie. Brzmienie przepisów przyszłej ustawy o szkolnictwie wyższym powinno nadto traktować umowę o pracę na czas nieokreślony jako podstawę stosowaną co do zasady, zawarcie umowy terminowej zaś odbywałoby się na zasadzie wyjątku w przypadkach precyzyjnie w ustawie określonych, bez konieczności odwoływania się do jakichkolwiek klauzul generalnych, w tym zwłaszcza kodeksowych.

${ }_{40}$ Por. art. 16 ust. 2 i art. 19 ustawy z dnia 21 listopada 2008 r. o pracownikach samorządowych (Dz. U. z 2016 r., poz. 902).

${ }^{41}$ Por. art. 4 ustawy z dnia 18 grudnia 1998 r. o pracownikach sądów i prokuratury (Dz. U. z 1998 r., Nr 162, poz. 1125). 


\section{Bibliografia}

\section{Literatura}

Baran K.W. (red.), Kodeks pracy. Komentarz, Warszawa 2012.

Baran K.W., O niektórych sposobach nawiązania umownego stosunku pracy, w: Wolność i sprawiedliwość w zatrudnieniu. Księga pamiątkowa poświęcona Prezydentowi Rzeczypospolitej Polskiej Profesorowi Lechowi Kaczyńskiemu, Seweryński M., Stelina J. (red.), Gdańsk 2012.

Baran K.W., Umowa o pracę na czas określony w ustawie o łagodzeniu skutków kryzysu ekonomicznego dla pracowników i przedsiębiorców, Monitor Prawa Pracy 2009, 9.

Gersdorf M., O przyczynowości zawarcia i rozwiąania umowy na czas określony, w: Stosunki zatrudnienia $w$ dwudziestoleciu społecznej gospodarki rynkowej. Księga pamiątkowa z okazji jubileuszu 40-lecia pracy naukowej Profesor Barbary Wagner, A. Sobczyk (red.), Warszawa 2010.

Jackowiak U., Problemy stabilności zatrudnienia asystentów i adiunktów szkół wyższych, Praca i Zabezpieczenie Społeczne 1987, 7.

Jackowiak U., Terminowe umowy o pracę a ochronna funkcja prawa pracy, Monitor Prawa Pracy 2004, 4.

Kuczyński T., w: System prawa administracyjnego, t. XI, Stosunek służbowy, Hauser R., Niewiadomski Z., Wróbel A. (red.), Warszawa 2011.

Kuczyński T., Komentarz do art. 118 ustawy Pr. o szk. wyższ., w: Akademickie prawo pracy. Komentarz do art. 107-158 oraz 196-201a i 226 ustawy Prawo o szkolnictwie wyższym, K.W. Baran (red.), Warszawa 2015.

Kuczyński T., Właściwości opisujące nawiązanie nominacyjnego stosunku pracy, w: Z aktualnych zagadnień prawa pracy i zabezpieczenia społecznego. Księga jubileuszowa Profesora Waleriana Sanetry, B. Cudowski, J. Iwulski (red.), Warszawa 2013.

Kwiek D., Antonowicz D., Brdulak J., Hulicka M., Jędrzejewski T., Kowalski R., Kulczycki E., Szadkowski K., Szot A., Wolszczak-Derlak J., Projekt założeń do ustawy Prawo o szkolnictwie wyższym, Poznań 2016.

Lekston M., Ciężkie naruszenie podstawowych obowiązków pracowniczych jako przyczyna rozwiązania stosunku pracy z nauczycielem akademickim, Studia z Zakresu Prawa Pracy i Polityki Społecznej 2012.

Lekston M., Dyferencjacja zatrudnienia w szkole wyższej. Analiza kryteriów, Studia z Zakresu Prawa Pracy i Polityki Społecznej 2010.

Łapiński K., Ograniczenia w zawieraniu umów terminowych w polskim prawie pracy, Monitor Prawa Pracy 2007.

Prawo o szkolnictwie wyższym. Komentarz, W. Sanetra, M. Wierzbowski (red.), Warszawa 2013.

Propozycja założeń do ustawy regulującej system szkolnictwa wyższego, H. Izdebski (red.), SWPS, Warszawa 2017.

Radwan A. (red.), Plus ratio quam vis consetudinis. Reforma nauki i akademii w ustawie 2.0, Kraków 2017. 
Sobczyk A., O czasie trwania umowy zawartej na czas określony, w: Z zagadnień współczesnego prawa pracy. Ksiega jubileuszowa Profesora Henryka Lewandowskiego, Z. Góral (red.), Warszawa 2009.

Stelina J., Charakter prawny stosunku pracy z mianowania, Gdańsk, 2005.

Stelina J., Przemiany stosunków pracy z mianowania, w: Współczesne problemy prawa pracy i ubezpieczeń społecznych, L. Florek, Ł. Pisarczyk (red.), Warszawa 2011.

Stelina J. (red.), Leksykon prawa pracy. 100 podstawowych pojęć, Warszawa 2008.

\section{Orzecznictwo}

Postanowienie SN z dnia 22 listopada 1979 r., III PZ, 7/79, Praca i Zabezpieczenie Społeczne 1981, 7.

Wyrok SN z dnia 19 marca 2008 r., I PK 263/07, Lex Polonica, nr 3051038.

Wyrok SN z dnia 4 kwietnia 2008 r., I PK 249/2007, Lex Polonica, nr 1958365.

Wyrok SN z dnia 4 września 2013 r., II PK 358/12, LEX, nr 1460947.

Wyrok SN z dnia 7 lipca 2005 r., II PK 351/04, OSNP 2006, nr 11-12, poz. 171.

Wyrok WSA w Gdańsku z dnia 24 lutego 2011, III SA/Gd 377/10, Legalis, nr 328550. 